\title{
Human, super-human, anti-human: The posthuman deep future in evolutionary science fiction
}

\section{MARIUSZ PISARSKI}

DOI: https://doi.org/10.31577/WLS.2021.13.1.1

The subject of creative evolution ${ }^{1}$ in recent science fiction is mostly presented in the near future with "cyberware" and "bioware" as basic tools for enhancing the body and the mind. This individualistic and hedonistic rendition of transhumanist ideals, often accompanied by a dystopian take on the socio-economic consequences of techno-enhancements, contradicts the original transhumanist agenda set by Julian Huxley, the founder of the movement, for whom the main goal was "a betterment" of all humankind (1957). It also stands in contrast to current discussions about the possible future within posthumanist and Anthropocene studies. By questioning the central position of humans on a symbolic, biological, and planetary level, the very position of humans among other species, and in nature itself, is being redefined. Principal questions arise: "What does it mean to be human?", "What are special and truly unique human traits?", and "Which of them make Homo sapiens stronger and which make Homo sapiens weaker in the 'evolutionary race'?" The answers that can be found in near-future science fiction are not always satisfactory. The advance of posthumanism in critical theory and literary criticism has produced a strong anti-anthropocentric, reductionist, and materialistic perspective on humans, bringing us closer to animals (Agamben 2004, 75-77), machines (Hayles 2002, 141), or indeed any non-human other (Braidotti 2013, 2-5). Blurring the boundaries of humans is often made by emphasizing the relational rather than autonomous character of organisms, which promotes hybridity. The focus is on sympoiesis (Haraway 2016, 58-59) and co-evolution, rather than autopoiesis, as the evolutionary pattern and ultimate way of defining life (Ferrando 2019, 141). "Earthlings are never alone," asserts Haraway, and one cannot argue against such a statement. Nonetheless, the posthuman deconstructions, according to which a human equals an animal, machine, or any non-human, might not bring us closer to re-investigating the problem of humanity's uniqueness. N. Katherine Hayles rightly points out that Claude Shannon's probability function, which was used in the "AI [artificial intelligence] fantasy of Hans Moravec", has gone far beyond its original context and was inappropriately applied to a much more complex phenomena of consciousness (Hayles 2011, 296). As a result, popular fiction and pop culture embrace the oversim-

* This article was supported by the project APVV-17-0064 "Analysis of multidimensional forms of trans- and post-humanism". 
plistic motifs of the posthumanist future. The dismantling of divisions between life and death, the organic and the synthetic, and the natural and the artificial - a strategy abundant in cyberpunk and discussed already in the postmodern context (McCaffery 1991), biopunk fiction (Schmeink 2017, 82-83), social science fiction (Mazis 2008, 130), and popular science-fiction movies (Micali 2019) - takes us even further from the re-investigation of humanity's own standing among other forms of life.

This essay attempts to look at selected literary examples from the tradition of far-future evolutionary science fiction (Clute et al. 2019) particularly in the works of the British authors J.B.S. Haldane, Olaf Stapledon, Stephen Baxter and Adrian Tchaikovsky. The genre's narrative focus is often set on the posthuman deep future (Stager 2011), where a global catastrophe has accelerated changes in human life, resulting in either a decline, a devolution, or a forced departure from Earth in search for alternative habitats. Because its main subject is the possible course of human development over millions of years, which is quite often riddled with numerous disasters, far-future science fiction does not shy away from general questions about the nature of humanity, its place among other species, and the chances of its evolutionary success and progress.

This argument will be supported by the reflections of Jean-François Lyotard on the possibility of intelligence after the heat death of the Sun, outside of the body and the Earth itself (1988), and Stanisław Lem's reflections on humans' odds in the "evolutionary race" (1996), ideal homeostasis, and the important distinction between evolutionary progress and success. Surprisingly, neither author has been extensively quoted in the transhumanist context. It is also no coincidence that several of the authors discussed below (Lem, Haldane, and Tchaikovsky) are biologists by education or profession. This gives them a unique position which favours a much more agnostic stance towards technology, the logic of evolution, and the place of humans within it.

The most striking result of viewing contemporary discourses on the possible near future from the standpoint of visionaries of the far future is, somewhat paradoxically, a theoretical reversal of positions between posthumanist and transhumanist agendas ${ }^{2}$. Today, transhumanist efforts to enhance human capabilities and push humanity's limitations through computer technologies, bioengineering, and any other available means might look retrograde in the context of the progressive dethronement of humans from their central position in the symbolic realm. Posthumanism tries to diminish the cultural, ecological, and psychological damage the Vitruvian Man of the Enlightenment brought in his wake (Braidotti 2013, 13). However, the more one goes into the future, the less relevant the socio-economic considerations of posthumanism become. When humankind faces an existential threat, there is simply "no space left for deconstructionist practices" - the latter being a common reproach towards overly progressivist and techno-reductionist assimilations of existence on the part of transhumanism (Ferrando 2019, 27). Instead, technologies of human enhancement based on biotechnology and AI emerge as the only means of survival. Authors of speculative fiction that had narrative timelines stretching for millions of years expressed this as early as in the 1920s. Of course, in survival mode, regenerative medicine, radical life extension, mind uploading, cryonics, and other 
techno-enhancements, or "enchantments", advocated by transhumanism are also put on hold. In other words, it is neither the post-chthonic hybrid human, who lives in harmony with nature, nor the fully evolved compassionate posthuman, attuned to all forms of otherness, who survives the planetary disasters of the far future. It is the transhumanist $\mathrm{H}+$, or human 2.0 , built thanks to human ingenuity. It is only as an enhanced species, a product of an accelerated evolution, that humans have the best chance to carry the "immortal gene" (Kováč 2015, 116) beyond the body and beyond Earth itself.

Deep future speculation in fiction and philosophy envisions seemingly paradoxical scenarios that are both anti-human and anthropocentric at the same time. These scenarios are anti-human because evolutionary success might rather belong to spiders, ants, or body-machine hybrids, or might altogether enter the exo-biological realm. They are anthropocentric because these modes of extension of life are achieved by a prompt, focused, and collaborative effort that only one species on Earth - the human species - represents. In line with humankind's history of migrations, starting from the Great Human Migration, visions of the deep future suggest that being human means to be a perpetual refugee, escaping from evolutionary pressures and planetary upheavals. Ultimately the constant mutation, selection, and genetic drift (Gouyon et al. 2007, 90) can force the deep future migration beyond the human body and beyond Earth. Yet, at least in literary visions, this future emigré remains a human.

\section{GENETIC ENGINEERING AS A TOOL FOR SURVIVAL: THE FAR FUTURE OF J.B.S. HALDANE}

If modern science fiction takes its origins in the scientific romances and essays of H.G. Wells, then evolutionary science fiction takes most of its subsequent themes from J.B.S. Haldane, the British-Indian biologist, eugenicist and a visionary known for his works in physiology, genetics, evolutionary biology which inspired Olaf Stapledon, Aldous Huxley and many other prominent pioneers of science-fiction and dystopian literature (Adams 2000, 485). Inspired by Darwinian thought, geological and astronomical discoveries of the early 20th century, and Wells's visions of the far future, ${ }^{3}$ Haldane's essay on evolutionary biology, "Daedalus; or, Science and the Future", was presented in 1923 and published the following year in the magazine Today \& Tomorrow (Clute et al. 2019). This reflection on future applications of biotechnology, resulting in the "abolition" of disease and old age, genetic enhancements, and the possible immortality of humankind, inspired a series of futurological articles by Julian Huxley, Bertrand Russell, and other prominent writers and philosophers. On the wave of this intellectual ferment, Haldane wrote Possible Worlds and Other Essays (1927), from which the final essay, "The Last Judgment", dramatically developed his prophecies in an effort to envision the consequences of creative evolution millions of years into the future.

The "most probable end" of our planet happens in Haldane's story five million years in the future. People are harvesting the energy of tides from the enlarged Moon, living their lives to their fullest by engaging in creative and scientific activities, and 
reaching the age of three thousand. Yet this transhumanist-like happiness does not last long. Informed by advancements in modern astrophysics, specifically the lectures of James H. Jeans on the Sun's life cycle (Adams 2000, 463), Haldane introduces a scientifically supported narrative event: the overheating of the Sun and the scorching of the Earth. The catastrophe of cosmic proportions gives people - in the author's own words - "as much chance of survival as a butterfly in a furnace." By the year $9,000,000$, humankind is seeking solutions, firstly in space exploration and secondly in genetic engineering. A large-scale programme of human enhancement focusing on the adaptation to conditions on other planets (Venus and Jupiter) is launched with the goal of extending humans' existence beyond Earth. The story of mankind ends with the destruction of the Earth and the emergence of a super-organism as a highly connected, adaptable, and endurable posthuman society. From the point of view of the super-organism, who manages to survive and evolve to a higher plane of consciousness, the destruction of its home planet was an episode of "entirely negligible importance". Haldane concludes: "And there are other galaxies [...]."4

The significance of "The Last Judgment" lies in its introduction of a wide range of semantic tropes associated with human evolution, enhancement, and possible responses to the prospect of extinction introduced by the work. The themes of the heat death of the Sun, the disintegration of the Moon, the emergence of a collective mind, the terraforming of other planets, and pantropy - a notion of biologically enhancing humans for a life outside of Earth - would become common across different genres of science fiction and would be further advanced in evolutionary science fiction, from Olaf Stapledon's Last and First Men: A Story of the Near and Far Future (1930) to Stephen Baxter's Evolution (2003) and Michel Houellebecq's evolutionary satire The Possibility of an Island (2005). One key element in Haldane's vision of the future was missing. This was a world without machines and machine intelligence. Being a biologist himself - and fascinated with momentous developments in modern physics, from Planck to Einstein and Heisenberg - Haldane tailored his vision accordingly. Perhaps as a consequence, the genetically modified life forms that are sent on colonizing missions to Venus and Jupiter are presented as subservient and benevolent. The motif of revolt, so frequent in the context of AI, cyborgs, and robots, is absent. Subsequent works of science fiction, even the Last and First Men written by Haldane's direct successor Stapledon, would significantly broaden the futurological palette by including machines as our co-habitants, the carriers of human civilization, and our most endurable successors.

In many regards, "The Last Judgment" remains original, future-proof, and relevant. With consequence and in brush strokes, Haldane draws a dividing line between those who have evolved and those who have not, and between those who sacrifice individual happiness for collective survival. A crew that came back from a long-lasting mission to Venus was unable to forge a "fertile union" with the evolved inhabitants of the dying Earth. This put them automatically in a subjugated position. The crew was rendered ineffectual to society, and they were consequently used in biological experiments. That part of society that did not support the idea of accelerated evolutionary change, and who preferred to maintain their existing yet illusory homeo- 
stasis, was also marginalized. These were the enhanced trans-humans, who enjoyed a long life of three thousand years and "lived in accordance with instincts which were gratified" (Haldane 2009, 303):

Those members of mankind who were once more evolving were not happy. They were out of harmony with their surroundings. Disease and crime reappeared among them. For disease is only a failure of bodily function to adjust itself to the environment, and crime a similar failure in behaviour. But disease and crime, as much as heroism and martyrdom, are part of the price which must be paid for evolution.

Haldane introduced a clear distinction between individual and collective happiness, and decidedly pointed to the latter as the route to the survival of the human race. Thanks to an extra sense of radiation that was bioengineered in order to survive on Venus, people gained ultra-fast and telepathic abilities of communication. Radiation quickly turned into a medium of control and discipline. The connected super-organism, a prototype of many "hive minds" in later science fiction, cared little for the individual and his needs. Yet the price paid by the individual - as Haldane puts it - was paid back by the race and the goal of surviving and carrying life beyond Earth was achieved.

Despite it being an early venture into the futuristic speculation of the far future based on and extrapolated from scientific evidence available at the time, Haldane's "The Last Judgment" manages to introduce the main themes of evolutionary science fiction and establish a discursive framework which is still relevant within transhumanist and posthumanist discourse. Two crucial points about the future of biotechnology and evolution are made in "The Last Judgment". They go beyond a single narrative motif, or technological prophecy, and venture into the area of continuing debate on socio-economic, bio-ethical, and pragmatic aspects of human enhancement. The first one can be labelled as "enforced solidarity" and the second as a "suspension of individuality". Rather unpopular in posthumanist research, which is ex definitione emancipatory and pro-individualistic, and mostly invoked in the transhumanist context within a specialized niche of disaster prevention (Bostrom 2013), these issues might sooner or later leave the confines of fiction. The collective scientific effort in the face of the Covid-19 pandemic, which has resulted in the development of a vaccine in an unprecedented time frame of less than one year, might be the best current example of the importance of collective action towards a common goal that Haldane had advocated one hundred years ago.

\section{THE EVOLUTIONARY VISIONS OF OLAF STAPLEDON}

Last and First Men: A Story of the Near and Far Future (1930) and its sequel Star Maker (1937) continued the British pre-war fascination with scenarios of the far future, human evolution, and the life on other planets. Influenced by Henri Bergson (Stableford 2006, 196), Haldane, and Jean-Baptiste de Lamarck rather than Charles Darwin, Olaf Stapledon presented an epic futurologist fantasy which is mostly earthbound yet still of cosmic proportions. In Stapledon's vision, eighteen different species

of man rise, fall, and finally succumb to the heat death of the solar system. In his depictions of the coming and going of civilizations, Stapledon puts the ideas present in Haldane's work to the test. Many derive from pursuing happiness through genetic 
engineering and an accelerated evolution of specific sets of physiological and psychological traits. Some enhancements are possible thanks to technology inherited from conquered Martian invaders, although on a moderate scale. Most of the changes come from biological interventions and forced adaptation due to the changing geological patterns. There are flying sapiens, spiritual revival sapiens, and sapiens with extremely enlarged brains that take up most of their body mass and make humans inseparable from their communication devices; there are also highly telepathic sapiens who evolve to form a single hive mind. The hive mind and telepathic connection of beings is represented by the last species, the Eighteenth Man, who narrates the million-year-old story of humankind. Through such narrative framing, the Eighteenth Man "connects" with the First Man for whom the story is directed.

The narrative does not follow a strictly causal succession of events, but rather a rhythm of cycles of evolution and devolution shaped according to Hegelian dialectics. In a clearly Lamarckian take on evolution (Nowicki 2014, 41-42), Stapledon's humans evolve in line with their most characteristic traits. These traits, when perfected, fall victim to some other aspects of physiology, psychology, or technology which were overshadowed by the growth of the prime features. This, in turn, triggers processes of devolution into sub-humans or to near extinction. As such, the struggle and conflicts in Stapledon's world are mostly internal, human-centred, and earthbound. Evolutionary cycles do produce some outstanding examples of humanity which, on a level above a single human species and its civilization, seem to defy the laws of entropy. In his address to the First Man, the Last Man - fully evolved and representing the highest achievement of evolution - reflects on the whole of humanity and embraces the shared values that persist throughout all eras.

Nevertheless, the transhumanist fulfilment in Stapledon's story is not eternal and eventually has to succumb to forces much stronger than any human weakness or invention - nature itself. Faced with the ultimate death sentence for the planet the impending overheating of the Sun - the Last Man is left with limited choices. One remaining option is the unification of individuals and an immersive self-reflection on the whole of humanity made possible by "telepathic" brain implants. Even the final departure from Earth to Neptune is not a permanent solution, as a "supernova" is devouring the whole of the solar system. The last stance of the human race is to devise a virus and propel it into other systems in the hope that it propagates life elsewhere in the universe.

Early far-future speculative fiction, as shown by Haldane and Stapledon, takes an optimistic view on humanity, which is able to perform collective action on a global scale and unite in the face of planetary disaster. Regardless of whether this solidarity is literal, embodied, or forced, it achieves its goal of preservation of life and human values. In one form (the super-organism on Venus in the case of Haldane) or another (genetic material sent into outer space in the case of Stapledon) humankind, or its avatars, is able to survive thanks to its ingenuity, collaboration, and technology, which translates into successful pantropy made possible by genetic enhancements and the successful terraforming of other planets, where life can continue. A different story is presented in post-war and contemporary science fiction. 


\section{EVOLUTION IN CONTEMPORARY HARD SCIENCE FICTION}

Informed by the historical experience of the Holocaust, the discredited science of eugenics, the Cold War, the adventures of global capitalism, and the emergence of computer technologies, contemporary science fiction directed its scientifically supported visions of the far future into much more sombre and pessimistic outputs. A telling example of such tendencies is Evolution (2003) by the British author Stephen Baxter. Following the formula of H.G. Wells's The Outline of History (1920), Evolution is a collection of nine "books" which give an account of the history of the universe from its origins to its ultimate extinction, bringing a strong and remarkable statement about the human impact on the history of our planet. However, according to Baxter, this impact is ultimately marginal. In the story, a single geological event, the eruption of a super-volcano in the middle of the 21 st century, at a time when people are sending AI drones to Mars and struggling to reach an agreement on climate change, is enough to wipe out most of humanity and all of civilization. From then on, evolution takes its own course and is uninterrupted by any human intervention.

Baxter's vision departs from that of Haldane and Stapledon. These pioneers of evolutionary science fiction gave humankind the upper hand in facing planetary disasters. However, this sounds especially crude and ironic in the context of posthumanism and transhumanism. Five hundred million years after the extinction of modern humans, a descendant of the AI drones sent to Mars in the 21st century lands on Earth to find its inhabitants living in small and scattered communities and unable to communicate with the visitor. No civilization is to be found; there is no technology, no cyberspace, and no trace of a collective or super-organism. Instead of Bergson's L'Évolution créatrice (1907; Creative Evolution, 1911), people had to passively allow evolution to turn in the direction most suitable for itself. As a result, not unlike Wells's Morlocks, people live underground and in symbiosis with trees, whose underground roots deliver shelter and nutrition. Outside there is only a scorched Earth and extreme heat and radiation from the Sun in its deadly Red Giant phase.

Baxter's contribution to the tradition of evolutionary science fiction and to contemporary posthumanist discourse can be encapsulated in his rendition of a few key motifs. The notion of a super-organism that is able to endure changing geological conditions is sustained, but it is greatly reduced to a local level of plant-human symbiosis. This organism is surely able to survive, but it cannot do much more than that. The dream of people living in harmony with nature, which is close to ecological posthumanism, is presented in its most grotesque implementation. As far as posthumanist motifs are concerned, Evolution introduces a clear winner of "paradise engineering" (Pearce 1995), and it is neither posthuman nor super-human; it is a machine. The co-evolution of humans and machines is disrupted and leaves the non-human part of such a techno-genesis the sole remaining participant. When most of the human population died in the aftermath of the eruption of the super-volcano, NASA robots stayed on Mars. They were programmed to mine resources and prepare the infrastructure for a human colony. The mission's side project was a "machine reproduction" experiment carried out by AI specialists. One of the robots, a prototype named John Van Neumann, managed to reproduce itself, and soon other robots followed. 
With no humans to regulate reproduction growth - after thousands of years and exhaustive wars for resources - robots destroyed the planet core of Mars. Thanks to the development of sun sails, thermonuclear fusion, and anti-matter engines, swarms of replicants were able to disperse across space, and one day their representative arrived on Earth in search of its origins.

Although the possibility of machines being able to self-replicate is a common motif in science fiction, this has also been taken into consideration by science. Stephen Hawking pointed out that with the emergence of AI, machines might be able to "take off on their own" and re-design themselves. In such a case, humans, a species limited by slow biological evolution, would not be able to "compete" in the evolutionary race, and, as Hawking puts it, they "would be superseded" (Cellan-Jones 2014). A similar course of events was explored by Stanisław Lem, both in his parodic takes on common tropes of science fiction and in his non-fiction. In Dialogues ([1957] 1996), Lem directly addressed Julian Huxley's ideas of human enhancement and controlled evolution.

Taking a starting point in homeostasis as the mechanism of adaptation, Lem rejects Huxley's anthropocentric criteria of "evolutionary progress" with humans at its centre by distinguishing between success and progress in evolution. Evolutionary success is best represented by insects which - having not changed much in biological form for millions of years - have been able to endure even major planetary cataclysms. Lem argues that, if the goal of evolution is survival and the preservation of life, insects are much better equipped for this achievement than humans, even if humans are much further along than insects in terms of evolutionary progress. However, according to Lem, it is machines that are in a better position than humans and insects:

From a clearly organizational, statistical, and also adaptational standpoint, by replacing biological forms, machines are not only able to create a uniform, autonomous "planetary homeostat", but they also constitute a solution more stable and more efficient than human civilization (2012, 487; trans. M.P.).

Baxter's Evolution supports Lem's predictions. If the transhumanist vision of a happier future through technology is an expression of anthropocentric exceptionalism (Ferrando 2019, 30), then Baxter offers an ironic turn of the advocated dethronement of humans. The accidental successor to human civilization is the human-created machine, whose intelligence and technology evolved on their own. However, when facing the heat death of the human world, the vacant position in the centre of the human-perceived universe - vacant because posthuman tree dwellers live outside of the symbolic space - is not even considered by the descendants of Martian robots. The machine leaves Earth and has no will to come back.

When the super-volcano erupts in Evolution, the people who should be most interested in securing humanity's future are engaged in bitter political conflict on a global scale. Scientists are caught between hard-line environmentalists, who would gladly see a stop to technological progress, and well-to-do transhumanists with their designer babies, who believe in the betterment of individuals through genetic and computer enhancement. However, not even the rich manage to escape the inevitable. There is 
not much time to make a rescue plan, and within months most of the life on Earth has vanished. In Neal Stephenson's Seveneves (2015), humanity witnesses the disintegration of the Moon. What would follow is a deadly rain of burning lunar matter that - as scientists calculated - completely destroys the surface of the Earth and only stops after five thousand years. With not much time left to build an orbital ark that would ensure that the descendants of all human, plant, and animal species re-populate Earth in the distant future, socio-economic divisions arise. The survival effort starts in a genuinely humane, humanitarian, and egalitarian fashion under the auspices of the United Nations and according to a formula of diversity. However, ultimately human ambition and disagreements between the crews of the survival ships lead to struggles and accidents in orbit, and only seven people - all women - survive. The generations who would re-populate Earth a few thousand years later would be the direct descendants of these seven survivors, having been born with the help of preserved genetic material from deceased men.

The logic of biology and evolution, if applied equally to humans, animals, and machines, and with the inclusion of exobiological outcomes, seems to privilege machines, which stand a much higher chance of survival in the face of a planetary catastrophe. A self-replicating and intelligent product of human technology is able to become something more than in Hawking's warning. It does not always constitute an existential threat, and in scenarios unfavourable to man, it may actually serve as a guarantee, extension, and representative of human ingenuity and civilization.

\section{HUMANS, SPIDERS, AND OCTOPI: BIOENGINEERING POSTHUMAN FUTURES IN ADRIAN TCHAIKOVSKY'S FICTION}

The pattern of failure, chance discovery, and narrow survival, originating in personal conflicts and a disorderly fragmentation of societies in the face of disaster - something which Haldane's and Stapledon's idealistic visions of the far future did not embrace - also comes to the fore in Adrian Tchaikovsky's Children of Time (2015) and to a lesser extent in Children of Ruin (2019). Lem's emphasis on insects as species with a better chance of revolutionary success is fully expressed in the first of Tchaikovsky's novels. War-torn humanity has begun to venture into outer space, and several terraforming and "uplifting" projects are carried out. One of these evolutionary experiments goes wrong after it is sabotaged by a crew member. A capsule with monkeys - who were to be injected with an "uplifting" nano-virus of self-awareness in order to populate the planet - is damaged, and the virus finds its way into spiders instead. Sabotage and revolt forces the leader of the project, Avrana Kern, to upload herself into her ship's computer and in this way oversee a thousand years of accelerated evolution and the growth of civilization on the planet. Five thousand years later, a wrecked ship with hibernated survivors from Earth arrives and encounters a sophisticated society of spiders, who themselves are able to direct the evolution of other creatures (such as ants and beetles) on their planet. Kern, who by then has no physical presence, instructs the spiders to allow the landing of the human crew only if the survivors from Earth are injected with another nano-virus, which discharges self-destructive human traits from the genome and allows 
for peaceful co-habitation with the uplifted insects. Only then are the humans ready to live on the new planet with the spiders as their hosts and neighbours. Through neural translating devices, the spiders' language, based on leg tapping and stroking, is understandable to humans and vice versa. A new civilization of spiders and humans is born.

Tchaikovsky, who after Haldane and Lem is the third author with academic background in natural science (Haldane was a distinguished biologist, Lem graduated in a degree in biology, Tchaikovsky studied zoology), contrasts the downfall of humans with the rise of intelligent spiders in a way that conforms both to the intuitions of Haldane about the advantages of the super-organism and collective action and Lem's arguments about the adaptive abilities of insects. Bruised, battered, and socially downgraded to the level of medieval feudalism, the humans' only chance of survival is a forced pantropy that makes men more empathic towards other species.

In the sequel, Children of Ruin, a book which has similar evolutionary and bioengineering themes, the British author establishes uplifted octopi as the only intelligent survivors of a failed terraforming mission. A thousand years after the death of the last member of a human crew, octopi develop their own orbital society. Just like the descendants of the Martian robots from Baxter's Evolution, they are aware of their human ancestry, yet when confronted with visitors from the spider-and-human civilization, they prefer to remain alien to them.

The fate of humanity and the ultimate judgement of humanity's moral standing in Children of Time depends on the decision of the computer program, i.e., Kern's uploaded consciousness. The chief scientist of the original terraforming project and the uplifting of monkeys had decided to upload her mind into a computer in order to oversee hundreds of years of accelerated evolution on the planet. She herself is aware of her diminished humanity outside of the body. Her human feelings and emotions wither with time, and ultimately she is presented as a piece of highly intelligent software rather than as an uploaded human; she is a mind fully aware of her digital limitations as a "binary ghost". Kern's case does not conform to Hans Moravec's vision of intelligent robots and uploaded human intelligence (Moravec 1988). Instead, her depiction is more in line with Jean-François Lyotard's reservations about the possibility of an exobiological basis for life and consciousness, which, in his view, is not able to deliver "transcendence in immanence". For the French philosopher, and for Husserl, who is quoted in this context, human thought operates within a field of orientation and expectation where it becomes aware of its horizons and aims at a "noema" which allows for the provision of intuitive and hypothetical configurations (Lyotard 1988, 80). There is no hardware other than the body that would support an analogical relationship to such an asynchronous and non-sequential process. Real "analogy", Lyotard states, requires a thinking or representing machine to be "in its data", just as the eye is in the visual field or writing is in language. To truly support the uploading of minds onto exobiological hardware, the hardware would need to support a special kind of thought:

[A] thought that proceeds analogically and only analogically - but not logically. A thought in which therefore procedures of the type - "just as ... so likewise ..." or "as if ... then" or 
again "as $\mathrm{p}$ is to $\mathrm{q}$, so $\mathrm{r}$ is to $\mathrm{s}$ " are privileged compared to digital procedures of the type "if ... then ..." and "p is not non-p". Now these are the paradoxical operations that constitute the experience of a body, of an "actual" or phenomenological body in its space-time continuum of sensibility and perception $(1988,81)$.

When applying Lyotard's categories to Tchaikovsky's portrayal of Kern, the ambivalent midway position Kern occupies between human and machine intelligence becomes clear. Kern is losing her memories, and quite often it is only thanks to her virtual assistant Eliza that some human thoughts, emotions, and images from her past life can resurface. However, if they do come into Kern's awareness, the construct behaves just like a human, raging with emotion and vehemently executing her self-righteousness. Paradoxically though, and in line with Lyotard's findings, Kern displays a lack of the broader and human "horizon" in her protective stance towards the planet, despite the unique circumstance of the visitors turning out to be the only survivors from Earth. Kern behaves more like a computer program, acting according to a binary logic when defending "her planet" and "her monkeys": "I do not recognize you. You are not human. You are not from Earth" - she broadcasts to the visitors "You are monkeys of the lower kind. My monkeys are being uplifted. They are pure. You mean nothing to me" (Tchaikovsky 2016, 92). As an uploaded mind and a form of AI, Kern perceives herself as a higher kind of human, yet she repeats the very divisive and faction-prone mode of behavior she wanted "her monkeys" to avoid and never repeat on "her planet".

In the end, the moral conundrum is resolved with a utilitarian impulse which elevates Kern to a more sentient and empathic form of AI, or a posthuman. Kern agrees to let the crew in, but she makes the spiders inject them with the nano-virus which, apart from ensuring co-habitation on the planet, dissolves the warlike, divisive, individualistic, and overly competitive edge of human nature.

In stressing the importance of biological embodiment, which greatly outmatches the consciousness-carrying capacity of a technologically induced simulacrum, or a fully functioning consciousness pattern, Tchaikovsky distances his vision from the Computational Theory of Mind (Panksepp 2017, 145) and the optimistic digital survival utopias of post-singularity (Vinge 2017, 352). Kern is closer to Dixi Flatline from William Gibson's Neuromancer (1984) as a digital approximation of the consciousness and memories of the late self, and devoid of human traits and the very "feeling" of being alive, than, for example, to Will Caster from the book and movie Transcendence, where upon awakening within a computer network, a former scientist retains his self-awareness and reports the sensation of being as free as ever, especially since his mental and intellectual abilities are multiplied (Micali 2019, 190).

\section{CONCLUSION}

The world of the far future shown in science fiction that takes the theory of evolution and biotechnology as the main reference for its vision does not subscribe to the Hegelian or Bergsonian moment of evolutionary triumph. Even the end-of-time scenarios of Haldane and Stapledon do not include the "cosmic point Omega" of Teilhard de Chardin. The highest, God-like point of development of human and cosmic con- 
sciousness (Pilsch 2017, 127) is far from being reached. Instead, the course of human history is most often diverted towards dark scenarios with disasters and existential risk at every turn. At best, the human condition is characterized by a constant state of banishment and the status of an eternal refugee, be it an Earthly or a cosmic one. At worst, it is marked by a curse of early extinction with narrow chances of the renewal of life on Earth and beyond.

Nevertheless, the benefits of the distant perspective far outweigh the somber outcomes it proclaims. Evolutionary fiction stands in the privileged position of going beyond the horizon of near-future science fiction. This directly translates to a change of focus from engagement in contemporary social discourse and practices to a more general reflection on existential and ethical issues related to the future of humanity. This position aligns evolutionary fiction with utilitarian concerns of these branches of transhumanism that focus, for example, on risk classification and prevention as well as scenarios of the progress (or regression) of humanity as measured by its technological maturity and survival capabilities (Bostrom 2013, 21-22).

Secondly, far-future fiction successfully suspends some theoretical conundrums: the priority of essentialist/relationalist and anthropocentric/anti-anthropocentric polarities is repositioned when humankind is facing planetary disasters. The social, political, and environmental consequences of human enhancement are delegated to the background when the whole of civilization is at risk and enhancement is a matter of urgency and the only condition for humanity survival (Haldane).

Thirdly, some of the envisioned scenarios of the far future discussed in this article can be understood as anti-human and anthropocentric at the same time. In Tchaikovsky's fiction, the uplifted and intelligent spiders are humanity's partners on their collective cosmic adventures. As such, this vision complies both with Lem's acknowledgement of insects as species that are more successful in finding their ecological niche in a posthuman world as well as with the dethronement of humanity in the post-Chthulucene perspective of Donna Haraway. Somewhat ironically, this co-habitation and co-evolution of humans and animals is possible only because of advanced biotechnology, a token of human ingenuity, and a technological effort expressed in techniques of enhancement, terraforming, pantropy, and mind uploading. In far-future science fiction, this trait of humanity is most often the only guarantee of life on Earth and beyond it.

\section{NOTES}

1 A thorough overview of posthumanist themes in near-future science fiction is given by Simona Micali, who provides an overview of the depiction of the not-distant consequences of technologies of human enhancement and growing division. See Micali 2019.

2 In the context of this paper posthumanism is understood as the "philosophy of our time", a continuation of postmodernism, and an umbrella term for a range of intellectual movements, including transhumanism. However, the focus of transhumanism on radical transformation of the human condition by existing, emerging, and speculative technologies is not entirely in line with the agenda of posthumanism. Despite shared interest around similar topics (nature of humanity, the future of mankind and of our planet) posthumanist distances itself from the anthropocentric perspective 
of the Enlightment which informs the "ultra-humanism" of transhumanism, see Ferrando 2019, 2728. See also the editorial note to this issue of World Literature Studies.

3 Especially relevant for the topic pursued by Haldane are Wells's The Man of the Year Million (1893), Time Machine (1895), and The First Man in the Moon (1900).

4 J.B.S. Haldane: Daedalus; or, Science and the Future, available at: https://www.marxists.org/archive/ haldane/works/1920s/daedalus.htm.

\section{LITERATURE}

Adams, Mark B. 2000. "Last Judgment: The Visionary Biology of J.B.S. Haldane." Journal of the History of Biology 33, 3: 457-491. DOI: https://doi.org/10.1023/A:1004891323595.

Agamben, Giorgio. 2004. The Open: Man and Animal. Trans. by Kevin Attell. Stanford, CA: Stanford University Press.

Baxter, Stephen. 2003. Evolution. London: Orion.

Bostrom, Nick. 2013. "Existential Risk Prevention as Global Priority." Global Policy 4, 1: 15-31. DOI: https://doi.org/10.1111/1758-5899.12002.

Braidotti, Rosi. 2013. The Posthuman. Cambridge: Polity Press.

Cellan-Jones, Rory. 2014. "Stephen Hawking Warns Artificial Intelligence Could End Mankind." BBC online. Accessed December 15, 2020. https://www.bbc.co.uk/news/technology-30290540.

Clute, John, David Langford, Peter Nicholls, and Graham Sleight. 2019. Encyclopedia of Science Fiction. Third Edition. Accessed December 15, 2020. http://www.sf-encyclopedia.com/entry/evolution.

Ferrando, Francesca. 2019. Philosophical Posthumanism. London: Bloomsbury Publishing.

Gibson, William. 1984. Neuromancer. New York, NY: Ace Books.

Gouyon, Pierre-Henri, Jean-Pierre Henry, and Jacques Arnould. 2007. Gene Avatars: The Neo-Darwinian Theory of Evolution. New York, NY: Springer Science \& Business Media. DOI: https://doi. org/10.1007/b114339.

Haldane, J.B.S. 1927. Possible Worlds. Accessed December 15, 2020. https://jbshaldane.org/ books/1927-Possible-Worlds/haldane-1927-possible-worlds.html\#Page_287 0.

Haldane, J.B.S. 2009. “The Last Judgment.” In Possible Worlds, ed. Carl A. Price, 287-312. New Brunswick and London: Transaction Publisher.

Haraway, Donna J. 2016. Staying with the Trouble: Making Kin in the Chthulucene. Durham and London: Duke University Press.

Hayles, N. Katherine. [1999] 2002. Writing Machines. Cambridge, MA: MIT Press.

Hayles, N. Katherine. 2011. "Wrestling with Transhumanism.” In Transhumanim and Its Critics, ed. by Gregory Hansell R. and William Grassie, 215-226. Philadelphia, PA: Metanexus Institute.

Houellebecq, Michel. 2006. The Possibility of an Island. Trans. by Gavin Bowd. London: Phoenix.

Huxley, Julian. 1957. New Bottles for New Wine: Ideology and Scientific Knowledge. New York, NY: Harper.

Kováč, Ladislav. 2015. Closing Human Evolution: Life in the Ultimate Age. Heidelberg: Springer. DOI: https://doi.org/10.1007/978-3-319-20660-8.

Lem, Stanisław. 2012. Dialogi. Warszawa: Biblioteka Gazety Wyborczej.

Lyotard, Jean-François. 1988. "Can Thought Go on without a Body?” Trans. by Bruce Boone and Lee Hildreth. Discourse 11, 1: 74-87.

Mazis, Glen A. 2008. Humans, Animals, Machines: Blurring Boundaries. New York, NY: State University of New York Press.

Micali, Simona. 2019. Towards a Posthuman Imagination in Literature and Media: Monsters, Mutants, Aliens, Artificial Beings. Oxford and New York, NY: Peter Lang.

McCaffery, Larry, ed. 1991. Storming the Reality Studio: A Casebook of Cyberpunk \& Postmodern Science Fiction. Durham, NC: Duke University Press.

Moravec, Hans. 1988. Mind Children: The Future of Robot and Human Intelligence. Harvard, MA: Harvard University Press. 
Nowicki, Piotr. 2014. "Lamarkowskie i darwinowskie ujęcie ewolucji gatunku ludzkiego." Poznańskie studia $z$ filozofii nauki 23, 2: 41-77.

Panksepp, Jaak. 2017. “Affective Consciousness.” In The Blackwell Companion to Consciousness. Second edition, ed. by Susan Schneider and Max Velmans, 141-156. Malden and Oxford: John Wiley \& Sons. DOI: https://doi.org/10.1002/9781119132363.ch10.

Pearce, David. 1995. “Hedonistic Imperative." Hedweb.com. Accessed December 15, 2020. http://www. hedonistic-imperative.com.

Pilsch, Andrew. 2017. Transhumanism: Evolutionary Futurism and the Human Technologies of Utopia. Minneapolis, MN and London: University of Minnesota Press.

Schmeink, Lars. 2017. Biopunk Dystopias Genetic Engineering, Society and Science Fiction. Liverpool: Liverpool University Press.

Stableford, Brian M. 2006. Science Fact and Science Fiction. An Encyclopedia. Oxon and New York, NY: Routledge/Taylor \& Francis.

Stager, Curt. 2011. Deep Future: The Next 100,000 Years of Life on Earth. London: Thomas Dunne Books. Stapledon, Olaf. 1930. Last and First Men: A Story of the Near and Far Future. London: Methuen \& Co. Stapledon, Olaf. 1937. Star Maker. London: Methuen \& Co.

Stephenson, Neal. 2015. Seveneves. London: The Borough Press.

Tchaikovsky, Adrian. 2015. Children of Time. New York, NY: Tor.

Tchaikovsky, Adrian. 2019. Children of Ruin. London: Pan Macmillan.

Tennesen, Michael. 2015. The Next Species: The Future of Evolution in the Aftermath of Man. New York, NY: Simon and Schuster.

Vinge, Vernor. 2017. "The Coming Technological Singularity: How to Survive in the Post-Human Era." In Science Fiction Criticism: An Anthology of Essential Writing, ed. by Rob Latham, 352-363. London: Bloomsbury, 352-363.

Wells, H.G. 1895. The Time Machine. London: William Heinemann. 
Speculative fiction. Science fiction. Comparative studies. Evolution. Transhumanism. Posthumanism. Human nature.

Posthumanist visions of the future do not venture further ahead than a few hundred or a few thousand years at most. It is within this near future that most scenarios of technological singularity and the enhancement of the human into an $\mathrm{H}+$, or a posthuman, are projected. This paper reflects on visions of much more distant futures found in evolutionary speculative fiction and science fiction, from J.B.S. Haldane (1927) through to Adrian Tchaikovsky (2019). From the vantage point of thousands (or millions) of years, the forthcoming era of mind uploading, designer babies, and technological immortality as envisioned in the transhumanist utopias of Hans Moravec amount to short episodes in a long cycle of evolutionary progress matched by planetary catastrophes. Such a perspective offers a more general reflection on the philosophical and cultural implications of a "creative evolution", the nature of humanity, and humans' place among other species. The transhumanism agenda, initiated by Julian Huxley in the form of a call to arms for the "betterment of humanity" by existing, emerging, and speculative technologies, does not emerge as a retrograde reinstatement of the compromised ideals of Enlightenment, but rather as the sine qua non for human survival in the face of the heat death of the Sun, the eruption of a super-volcano, and any other existential risk. Human ingenuity, reflected in advanced biotechnology, space travel, technological enhancements turns out to be the only guarantee of life on Earth and beyond it. As such, this comparative study of literary examples of possible courses of human history proves that reflections on the far future are capable of healing current discursive divides between posthumanist and transhumanist, anthropocentric and anti-anthropocentric, and technophobic and technophilic approaches to our present.

\author{
Mariusz Pisarski, PhD. \\ Centre for Bioethics \\ Department of Philosophy and Applied Philosophy \\ Faculty of Arts \\ University of Ss. Cyril and Methodius in Trnava \\ Nám. J. Herdu 2 \\ 91701 Trnava \\ Slovak Republic \\ m.pisarski@uw.edu.pl \\ ORCID: https://orcid.org/0000-0001-7038-0166
}

